\title{
EVALUATION OF FIELD JOB P RACTICE IMPLEMENTATION PROGRAM FOR THE STUDENT IS STATE VOCATIONAL HIGH SCHOOL 1 JAKARTA
}

\author{
Hawa Liberna \\ Program Studi Pendidikan Matematika, \\ FTMIPA, Universitas Indraprasta PGRI Jakarta. \\ email: liberna_h@yahoo.com
}

\begin{abstract}
ABSTRAK
Implementation of Hammond Model in Evaluation of Field Work Practice Program of State Vocational High School 1 Jakarta. The purpose of this study is to evaluate how the implementation of a program that has been selected in accordance with the purpose of information and implementation of a policy to take a decision. This research is taken one example of Hammond model implementation in Hammond model program evaluation one of program evaluation model that can help change learning to be better seen from 3 aspects that is learning, behavior, and institution. This Hammond program evaluation is a very helpful evaluation of the implementation of an existing school program for the better, in terms of these three aspects. In this research, the researcher evaluates the Field Work Practice program in STMN I Jakarta which has been running for more than 3 years and after the researcher conducted the research at State Vocational High School I many inputs from the researcher about the 3 aspects. And as an acceptable result is the implementation of Field Work Practices in Vocational Secondary School 1 will change its implementation in the first semester IX in the semester V. Because in the semester IX students sufficient knowledge to follow the implementation of Field Work Practices in the field to be better and competence.
\end{abstract}

Keywords: Hammond Model, Evaluation of Field Work Practice Program, 3 Cube Dimensions of Evaluation.

Vocational High School as an integral part of the education system in Indonesia plays an important role in improving human resources, especially in preparing middle workers. Vocational High School is an educational institution in the field of technology that prepares middle-level workers. This is in accordance with the Indonesian Law on National Education System that "vocational education is a secondary education that prepares students primarily to work in a particular field.

In accordance with the purpose of the Vocational High School, the graduate of Vocational High School Technical Skills Program Image is expected to master the technical drawings both in theory and practice in order to compete in the application of knowledge obtained in accordance with their field in the field of work. Vocational High School as one of the national education subsystem, has a very important position in the function of preparing skilled labor to support the national education system. The effort to prepare skilled manpower according to the needs of business and industry is approached through the "link and match" policy is the implementation of Field Work Practice activities.

The Field Work Practices implemented have several objectives: (1) Increasing knowledge of students in technology and industry. (2) Increase the competence (skill) of students in accordance with the competence of expertise. (3) Train students to have a high work ethic and work motivation. Train students to have initiative and creativity in performing their duties in the industrial world.

Based on the above description, one of the most important basic skills in employment for SMK graduates of the Image and Building Engineering Skills Program is the ability to draw buildings. In the second semester students of grade XI State Vocational High School 1 Jakarta must perform street vendors or conduct field work experience. Field work experience or field practice experience was conducted in class XI period 2. 
This policy requires both parties from the school and the field work together to develop the concept, it is intended that there is a suitability between school and the field. The conformity is intended to ensure that the competencies gained by students in the school is a required competence in employment in conveying technological progress to the school side to synchronize between the world of work in the field with the world at school. This policy is operationalized in the form of implementation of practical work in the field.

To implement PKL (Field Job Practice) in accordance with the vision of the school mission, each year sends the Building Materials Engineering Student XI class 2nd period for practical work for 4 months. However, in practice the work of this practice is still not as expected and the purpose of the program. Until now there are no institutions or individuals who examine specifically the impact of the implementation of the program street vendors, both the impact on alumni themselves and the impact on the work on the field.

Based on the results of interviews with the field and preliminary observations, practical work Image Skills Program and Building SMKN 1 Jakarta less well. This can be seen from the following indications: (1) Planning of field work that should be arranged jointly between the school and the field is not working properly and in fact only implemented unilaterally by the school without interference from the field. (2) In the implementation of street vendors, students are less armed with competence in their field of expertise, because the implementation of street vendors starts class XI semesters 5 and 6 so that many students are less in the field. (3) Monitoring conducted by supervisor is only limited to checking the presence of students in the field. (4) After carrying out practical work not all the expected competencies are achieved. (5) The existence of a couple institution is only limited to being a student practice place to carry out street vendors, this is evident from the tracking of the workforce on alumni only a few students work in companies.

Institution SMKN I Jakarta should have started to conduct a comprehensive evaluation of the program street vendors. As a form of school accountability to all the success of teaching and learning process in school. It is viewed from the purpose of street vendors can be said that through practical work activities in the field students are prepared to become a skilled workforce as well as professionals in the field.

PKL assessment involves assessing the process and results of the students' work while in the field covering aspects of reaction, institution, interaction, behavior and result. This assessment mainly contains how to determine the level of student success in mastering skills and behavior during street vendors. The guidelines for the implementation of street vendors as stated in the Curriculum of the Program of Image and Building Engineering Skills include assessors, assessed aspects, and assessment criteria. According to the Curriculum Program Expertise of Drawing and Building Engineering the guideline for the implementation of the assessment becomes the full authority of the field during the implementation of the street vendors. Schools only accept the results of the assessment from the field to then be converted to related subjects.

At the end of the street vendors, students will get results in the form of achievement value. The achievement is to recognize the ability possessed by students from the results of development in the field, namely: Technical aspects is the level of mastery of students' skills in completing the work (productive ability). Non technical aspect is the attitude and behavior of students during the business world and the industrial world that involves among others discipline, responsibility, obedience, and so forth. 
In this evaluation will examine the implementation of PKL programs in relation to education in the Program of Image and Building Engineering Skills. This research is an evaluative study by using model of Hamond at SMKN 1 Jakarta Program of Image and Building Engineering.

\section{METHOD}

Implementation of evaluation PKL SMK Negeri 1 Jakarta begins with a study mid-June 2016. To conduct surveys and monitoring of the implementation of Field Work Practice (PKL) to the field. Collecting observation data, the necessary interview later for the smooth evaluation of the Job Training Program (PKL) students in SMKN I Jakarta. The approach used in this research is qualitative research approach. The research method used in this research is the Hammond model method.

Please note, that the subject of research in the description of research results above are students of SMK Negeri 1 Jakarta force 2015/2016 who have implemented street vendors. Therefore, it is important to study further through evaluative research on the evaluation of PKL SMK N 1 Jakarta's program for students who are an integrated part of the PKL's competence.

This evaluation will examine the implementation of the Field Work Practice (PKL) program in relation to education in the Image and Building Engineering Program. This research is an evaluative study using Kirkpatrick and Hamond model in SMKN 1 Jakarta Image and Building Engineering Expertise Program. By applying a combined model of Kirkpatrik and Hammond. The Kirkpatric model is used to determine effectiveness. Both of these evaluation models combined are expected to develop very detailed evaluation questions from the dimensions of the Field Work Practice (PKL) program with each other.

In relation to that evaluation is not only aimed at collecting data, analyzing and presenting it, but giving input to the implementation of street vendors in order to improve the street vendors for SMKN 1 Jakarta in the future, in order to produce alumni in accordance with the needs of agencies (work units). Here are the evaluation criteria of SMK Negeri I Jakarta Field Work Practice Program:

Table 1. Evaluation Criteria of Field Job Practice Program (PKL

\begin{tabular}{|c|c|c|c|c|}
\hline No. & Aspect & $\begin{array}{l}\text { component } \\
\text { Evaluation }\end{array}$ & Indicator & Criteria \\
\hline \multirow[t]{2}{*}{1} & $\begin{array}{c}\text { INSTITUTIO } \\
\text { NS }\end{array}$ & $\begin{array}{l}\text { a. participants } \\
\text { PKL }\end{array}$ & $\begin{array}{l}\text { - PKL evaluating } \\
\text { requirements that } \\
\text { must be filled in } \\
\text { writing and } \\
\text { clearly by } \\
\text { participants PKL }\end{array}$ & $\begin{array}{l}\text { - } \text { Participants who have } \\
\text { met persyaratn PKL } \\
\text { PKL to enclose the } \\
\text { entire file } \\
\text { requirements PKL }\end{array}$ \\
\hline & & $\begin{array}{l}\text { b. Administratio } \\
\mathrm{n}\end{array}$ & $\begin{array}{l}\text { - Evaluating } \\
\text { administrative } \\
\text { requirements that } \\
\text { can support the } \\
\text { ongoing street } \\
\text { vendors street } \\
\text { vendors in the } \\
\text { field }\end{array}$ & $\begin{array}{l}\text { Participants of street } \\
\text { vendors who have } \\
\text { met the requirements } \\
\text { to enclose the entire } \\
\text { file PKL PKL } \\
\text { requirements }\end{array}$ \\
\hline
\end{tabular}




\begin{tabular}{|c|c|c|c|c|}
\hline No. & Aspect & $\begin{array}{l}\text { component } \\
\text { Evaluation }\end{array}$ & Indicator & Criteria \\
\hline & & c. community & $\begin{array}{l}\text { - Relations of } \\
\text { cooperation } \\
\text { between the } \\
\text { guidance } \\
\text { counselor at the } \\
\text { school and on the } \\
\text { field }\end{array}$ & $\begin{array}{l}\text { - Cooperative } \\
\text { relationship between } \\
\text { the tutor in the field } \\
\text { for the betterment of } \\
\text { the participants' } \\
\text { activities in the field } \\
\text { of street vendors }\end{array}$ \\
\hline \multirow[t]{3}{*}{2} & $\begin{array}{l}\text { INSTRUCTIO } \\
\mathrm{N}\end{array}$ & a. Organization & $\begin{array}{l}\text { Evaluate the } \\
\text { availability of } \\
\text { relevant } \\
\text { organizations and } \\
\text { schools; teachers } \\
\text { in accordance } \\
\text { with the } \\
\text { competencies that } \\
\text { will help the } \\
\text { process of } \\
\text { implementation } \\
\text { in the field of } \\
\text { street vendors }\end{array}$ & $\begin{array}{l}\text { An Institute of } \\
\text { teachers in schools, in } \\
\text { accordance with the } \\
\text { competencies that } \\
\text { will help the process } \\
\text { of implementation in } \\
\text { the field of street } \\
\text { vendors }\end{array}$ \\
\hline & & b. Method & $\begin{array}{l}\text { - Evaluating the } \\
\text { right method that } \\
\text { draws on the } \\
\text { experience of } \\
\text { learning that has } \\
\text { been planned and } \\
\text { written to assist } \\
\text { the } \\
\text { implementation } \\
\text { of street vendors }\end{array}$ & $\begin{array}{ll} & \text { Evaluation } \\
\text { questionnaire method }\end{array}$ \\
\hline & & c. Media & $\begin{array}{l}\text { - Evaluate the } \\
\text { availability of } \\
\text { appropriate } \\
\text { media to support } \\
\text { the } \\
\text { implementation } \\
\text { of street vendors } \\
\text { in the field }\end{array}$ & $\begin{array}{l}\text { Evaluation of media } \\
\text { observation autocad }\end{array}$ \\
\hline 3 & BEHAVIOR & a. cognitive & $\begin{array}{l}\text { - Psychomotor } \\
\text { knowledge test } \\
\text { after carrying out } \\
\text { street vendors in } \\
\text { the field }\end{array}$ & $\begin{array}{l}\text { Information } \\
\text { psychomotor } \\
\text { knowledge } \\
\text { assessment tests after } \\
\text { the students carry out } \\
\text { street vendors in the } \\
\text { field }\end{array}$ \\
\hline
\end{tabular}




\begin{tabular}{|c|c|c|c|c|}
\hline No. & Aspect & $\begin{array}{l}\text { component } \\
\text { Evaluation }\end{array}$ & Indicator & Criteria \\
\hline & & b. affective & $\begin{array}{l}\text { - Evaluating the } \\
\text { behavior that can } \\
\text { be shown to } \\
\text { participants after } \\
\text { completion } \\
\text { melaksanakn } \\
\text { street vendors } \\
\text { street vendors in } \\
\text { the field }\end{array}$ & $\begin{array}{l}\text { - Measuring behavior } \\
\text { can be shown to } \\
\text { participants after } \\
\text { completion carry out } \\
\text { street vendors street } \\
\text { vendors in the field }\end{array}$ \\
\hline & & c.Psikomotorik & $\begin{array}{l}\text { - Evaluate test } \\
\text { residential } \\
\text { building simple } \\
\text { picture complete }\end{array}$ & $\begin{array}{l}\text { Measure assessment } \\
\text { test component } \\
\text { applications simple } \\
\text { drawings of } \\
\text { residential buildings }\end{array}$ \\
\hline
\end{tabular}

\section{RESULTS}

1. Aspects Institution: Mechanical collection of information by analyzing administrative documents that must be fulfilled by the participants of Field Work Practice (PKL), Letter of submission of candidates Work Practice (PKL), this must be filled and completed by participants Work Practice (PKL) and unknown by: Head of expertise Program, Guardian Class, Professor BK / BP, the Candidate Work Practice (PKL)

Table 2. Instrument Institution (Pupil) Respondents Participants Students Work Practice (PKL)

\begin{tabular}{|l|c|c|}
\hline \multicolumn{1}{|c|}{ Category } & Frequency & Percentage \\
\hline Very unsatisfactory & 0 & $0 \%$ \\
\hline Not satisfactory & 2 & $3: 39 \%$ \\
\hline Neutral & 11 & $18.64 \%$ \\
\hline satisfy & 44 & $74.58 \%$ \\
\hline Very satisfactory & 2 & $3: 39 \%$ \\
\hline
\end{tabular}

Based on the conclusions of the questionnaire has been filled 59 participants Job Training (PKL), the analysis of the results table as follows: sequentially argue about the student gave a positive response with a satisfactory answer for $93.22 \%$ (55 respondents who answered satisfactorily from 59 the number of participants Work Practice (PKL).

Analysis Journal, in the journal there are some participants performance sheet Work Practice (PKL) which must be filled in and be known bycounselors at the school and in lapangan.Jurnal activity in the industrial practice of school counselors know pembmbing in school and on the field and the deputy head of the PR department of the industry.

Table 3. Analysis Instrument Institution (Society)

\begin{tabular}{|l|c|c|}
\hline \multicolumn{1}{|c|}{ Category } & Frequency & percentage \\
\hline Very unsatisfactory & 0 & $0 \%$ \\
\hline Not satisfactory & 0 & $0 \%$ \\
\hline Neutral & 2 & $3: 39 \%$ \\
\hline
\end{tabular}

52 JISAE. Volume 3 Number 2 September 2017. Copyright (C) Ikacana Publisher | ISSN: 2442-4919 


\begin{tabular}{|l|c|c|}
\hline satisfy & 57 & $96.61 \%$ \\
\hline Very satisfactory & 0 & $0 \%$ \\
\hline
\end{tabular}

The highest Pesentase visible on the question of the involvement of students following the Field Work Practice (PKL) in the field is helping needs of the workforce in the field and give a positive response with a satisfactory answer for $96.61 \%$ (57 respondents who answered satisfactorily than 59 the number of participants Field Work Practice (PKL).

2. Aspects of Instruction (Education):Availability of the organization in this regard is the teachers who are competent in the field according to their expertise. It is important to help students, to guide Work Practice (PKL), to determine which documents are appropriate teachers to their expertise of researchers conducted a survey to Administration (TU) SMKN 1 Jakarta to get a list of teachers at SMK I Jakarta neighborhood.

Table 4. Analysis Aspects of Instruction (Organization)

\begin{tabular}{|l|c|c|}
\hline \multicolumn{1}{|c|}{ Category } & Frequency & percentage \\
\hline Very unsatisfactory & 0 & $0 \%$ \\
\hline Not satisfactory & 0 & $0 \%$ \\
\hline Neutral & 3 & $5: 08 \%$ \\
\hline satisfy & 56 & $94.92 \%$ \\
\hline Very satisfactory & 0 & $0 \%$ \\
\hline
\end{tabular}

Of the 59 students who have participated in Field Work Practice (PKL) in the academic year 2015/2016 which has filled angkett about intruction aspects of the organization, the researchers concluded that, of the six questions presented on the average organization gave a positive response. The highest percentage seen on the question of, role of teachers and counselors in the field in Field Work Practice program (PKL), and give a positive response with a satisfactory answer for $94.92 \%$ (56 respondents who answered satisfactorily than 59 the number of participants Work Practice (PKL),

Table 5. Analysis Aspects of Instruction (Method)

\begin{tabular}{|l|c|c|}
\hline \multicolumn{1}{|c|}{ Category } & Frequency & percentage \\
\hline Very unsatisfactory & 0 & $0 \%$ \\
\hline Not satisfactory & 0 & $0 \%$ \\
\hline Neutral & 3 & $5: 08 \%$ \\
\hline satisfy & 56 & $94.92 \%$ \\
\hline Very satisfactory & 0 & $0 \%$ \\
\hline
\end{tabular}

The highest percentage seen on the question of, Conformity method with exercise / assignment and give a positive response with a satisfactory answer for 99.92\% (59 respondents who answered satisfactorily than 59 the number of participants Work Practice (PKL).

3. Aspects of Behavior Evaluation Results: Knowledge of psychomotor participants Work Practice (PKL) in the preparation of Field Work Practice (PKL) in the field. Cognitive behavior that will be prepared for the activities of Field Work Practice (PKL) is a cognitive psychomotor. Mechanical informing participants psychomotor knowledge Field Work Practice (PKL) is: to provide knowledge questionnaire psychomotor In the implementation of this cognitive aspect, researchers review the aspects of cognitive psychomotor and yes satisfactory results. Behavior that can be shown participant Work Practice (PKL) after completed the Field Work Practice (PKL) 
in the field, the assessment is contained in the journal Personality Value.

Implementation of Field Work Practice (PKL) at SMK I Jakarta, that during the execution of Field Work Practice (PKL) is set at SMK I Jakarta has achieved good cooperation between the school and enterprises concerned. It is characterized by the existence of an agreement or Memorandum of Understanding (MOU). Translation of an assessment of the achievement or success of the program Field Work Practice (PKL) at SMK I Jakarta, in achieving the goals that have been set, it can be seen from the list of searches graduate students of SMK I Jakarta, particularly the majors program engineering picture building work in related companies

\section{CONCLUSIONS}

Resources of the syllabus used in SMK Negeri 1 Jakarta is a competency-based syllabus of Curriculum 2013. From penulusuran that has researchers get the use of the syllabus at SMK Negeri 1 Jakarta have obeyed the rules. All take advantage of the existing syllabus in Curriculum 2013 has been implemented in terms of making the RPP, the processing of the learning activities, the provision of learning resources, and the development of research systems. All have been run well in SMK Negeri 1 Jakarta.

Then of resources that have been made lesson plan that relies on a syllabus that had been used earlier. All-making lesson plans, learning activities processing, and development assessment system. RPP has been set in referring to the syllabus used in the curriculum, 2013.

Assessing goal praketk progra field work in memebuhii requirements PKL participant document analysis results based on the requirements of the participants PKL researchers documents that it meets the requirements analysis yng procedure has been established from the Institution. Administrative resources to researchers analysis to determine the participants who will carry out street vendors Practice Fields. Participants Work Practice (PKL) must fulfill the administration issued by the Institute of street vendors in the schools.

Analysis of the questionnaire about the student's progress to the researchers conclude that the answers to get a positive response satisfactory, which means that the response from the public was very memuskan to be invited cooperation for the advancement of the implementation of street vendors. book document student progress is reported for students PKL falls spaciousness. Existing activities in the field entirely included into the book of student progress. The book of student progress is also very helpful in the process of communication between school counselors and mentors from the field. The book of student progress is also assist students in reporting all activities that have been done in the field.

Analysis of the organizational aspects of instruction, availability of relevant organizations / schools; teachers in accordance with the competencies that will assist in the implementation of street vendors in the field. Then the source of information about the document method, the proper method that draws on the experience of learning that has been planned and written to assist the implementation of PKL is already done. According to the analysis that the researchers can conclude that the method adopted for debriefing, PKL implementation is compliant with the existing competence. PKL Participants can accept the teaching and learning process in the classroom, particularly the field of study of building image receives instruction in accordance with the needs on the ground and the method used was in conformity with the theory presented. 
Analysis of psychomotor in the face of this it can be concluded that hasilya pretty good. The participants are always given tests psikomorotik every face, so that the results of questionnaire analysis psychomotor knowledge to researchers concluded that participants PKL gave a positive response on the test that it provides. The participants obtain satisfactory results therefore researchers consider that in the future the participants prepared melaksanakn street vendors street vendors in the field.

Sources of information affective, behavioral analysis that can be shown in schools PKL participants in the implementation of street vendors in the field. Namely, through the practice assessor book, the book is a practical assessment report submarine kegatan participants fulfilling their vendors street vendors in the field. All the work that has been carried out is recorded in the book as a practical assessment of assessment materials for the students carry out street vendors in the field. Evaluation of behavior that indicated the participants after completion of the field to carry out street vendors with their certificates. PKL certificate is a sign that students have been carrying out street vendors. This certificate is listed ratings for the participants do street vendors in the field as described in the discussion.

Resources psychomotor aspects of the analysis, the analysis of aspects of the preparation of students in the field psikomorotik in doing building work is to analyze the residence. In testing the ability of the ability to draw participants PKL then given a test sheet simple drawings of residential buildings. Students are asked to make drawings, the picture looks, image snippets and image detail. Here the ability of students were tested to where psychomotor abilities of students in the drawing. The results of the assessment of the investigators' analysis showed that students memuskan appreciable results. Within the meaning of students were able to complete the simple dwelling house engineering drawings. Then the questionnaire analysis to researchers conclude from the assessment of the program's objectives of cognitive, affective, and psychomotor psychomotor knowledge in the form of analysis of a total of 39 questions were undertaken by 59 participants of street vendors, the results show quite satisfactory appraiser. That is, the participants PKL was able to somewhat master the psychomotor knowledge for the provision of street vendors

Resources that result from the street vendors assess the program's objectives and institutional aspects of the reaction. Intruction and behavior, namely the Memorandum Of Understanding (MOU), and employment searches. Memorandum Of Understanding (MOU) is a form of cooperation by the institutions and the industry. The purpose of the Memorandum Of Understanding (MOU) to develop this competency Work Practice (PKL) in applying his knowledge Memorandum Of Understanding (MOU) is a form of cooperation of companies that have cooperated for a certain period means've seen the progress of the participants PKL as well as the seriousness of the participants PKL daalam run the job on the field. Memorandum Of Understanding (MOU) is a form of the seriousness of the participants PKL PKL in carrying out work in the field with the aim to develop competencies. Memorandum Of Understanding (MOU) can be seen the application into labor search the alumni. Labor search is very helpful party institutions to evaluate the presence of the participants of street vendors who have graduated from SMK Negeri 1 Jakarta. As a rule of motivation younger class.

\section{REFERENCES}

Abdus Sattar, 2011. Training and Development Strategy and Its Role in Organizational Performance. Journal of Public Administration and Governance: Vol. 1, No. 2 
Bada Haryadi, 2000. Competence Students of SMK In Component Cost Estimating Building. Journal of Research and Evaluation: No. 2, Year II

Djudju Sudjana, 2008. Evaluation of School Education Program. Bandung: Youth Rosdakarya.

Hammond, Robert L, 2001. Loval Level Evaluation at the US Department of Health, Education and Welfare Office of Education. Tucson, Arizona: Project Epic,

Ismail Yuksel, 2010. How to Conduct a Qualitative Evaluation Program in the Light of Eisner's Educational connoisseurship and Critisme Model. Turkish Online Journal of Qualitative Inquiry.

Lubis Grafura, Ari Wijayanti, 2014. Appropriate Education Curriculum Implementation Strategy Study, 2013 in SMK. Jakarta: Pustaka achievement

Ms. Pallavi, P. Kulkarni, 2013. A Literature Review on Training \& Development and Quality of Work Life. Journal of Arts, Science \& Commerce: Vol. IV, Issue 2.

Raja Abdul Ghafoor Khan, Furqan Ahmed Khan, Muhammad Aslam Khan, 2011. Impact of Training and Development on Organizational Performance. Global Journal of Management and Business Research: Vol. 11 Issue 7.

Soewarni, labor 2012.Kemampuan SMK. Yogyakarta.

Wirawan, 2011.Evaluasi Theory, Models, Standards, Applications, and Professional Jakarta: King Grafindo Persada.

Law of the Republic of Indonesia No. 20 of 2003 on National Education System.Bandung, Article 1, paragraph 12. 